\title{
Pengaruh Kenaikan Harga Bahan Bakar Minyak (BBM) Terhadap Pelayanan Transportasi Roda Dua di Pasar Tiga Putri Km 14 Banyuasin
}

\author{
Totok Sudiyanto \\ Fakultas Ekonomi Universitas PGRI Palembang \\ Email : totoktajir197@gmail.com
}

\begin{abstract}
ABSTRAK
Tujuan penelitian ini untuk mengetahui pengaruh kenaikan harga bahan bakar minyak (bbm) terhadap pelayanan transportasi roda dua di pasar Tiga Putri KM 14 Banyuasin. Populasi adalah pengojek yang biasa mangkal di pinggiran pasar Tiga Putri KM 14 Banyuasin yang berjumlah 100 orang pengojek. Sampel dalam penelitian ini berjumlah 50 orang pengojek di pasar $\mathrm{km} 5$ palembang.

Hasil penelitian diperoleh persamaan regresi linier sederhana $Y=16,615+0,528 X$. Nilai koefisien regresi kenaikan harga sebesar 0,528 dengan signifikansi $0,000 \%$ atau $0 \%<5 \%$ berarti signifikan untuk memprediksi nilai pelayanan. Dimana jika nilai $X$ naik sebesar satu satuan maka prediksi nilai $Y$ naik sebesar 0,528 dan sebaliknya jika berkurang satu satuan nilai $X$ maka prediksi nilai $Y$ berkurang sebesar 0,528 . Besarnya kontribusi dapat dilihat dari nilai koefisien determinasi diperoleh nilai $r^{2}=$ 0,322 . Hal tersebut dapat diartikan bahwa pelayanan yang dipengaruhi oleh kontribusi variabel kenaikan harga adalah $32,2 \%$, sedangkan sisanya $67,8 \%(100 \%-32,2 \%)$ di pengaruhi oleh variabel lain yang tidak ikut di teliti dalam penelitian ini.
\end{abstract}

Kata Kunci : Kenaikan Harga dan Pelayanan

\section{A. Latar Belakang}

Dalam kerangka makro-ekonomi, transportasi merupakan tulang pungggung perekonomian nasional, regional, dan lokal, baik di perkotaan maupun di pedesaan. Kebutuhan transportasi merupakan kebutuhan utama akibat aktivitas ekonomi, sosial, dan sebagainya. Dalam hal ini sarana transportasi yaitu angkutan umum, merupakan salah satu bentuk angkutan umum yang mempunyai fungsi sebagai sarana penggerak manusia untuk berpindah dari suatu tempat ke tempat lain, yang juga merupakan sarana transportasi alternatif di dalam kota, terutama bagi masyarakat yang tidak memiliki kendaraan pribadi. Sehingga kebutuhan akan sarana dan prasarana ini sangat diperlukan di wilayah perkotaan.

Kebijakan pemerintah untuk menaikan harga bahan bakar minyak (BBM) dalam negeri menyebabkan perubahan perekonomian secara drastis. Kenaikan BBM ini akan diikuti oleh naiknya harga barang-barang dan jasa-jasa di masyarakat. Kenaikan harga barang dan jasa ini menyebabkan tingkat inflasi di Indonesia mengalami kenaikan dan mempersulit perekonomian masyarakat terutama bagi sopir angkutan roda dua. Sehingga permintaan dari masyarakat akan berkurang karena harga biaya ongkos yang ditawarkan mengalami kenaikan. Begitu juga dengan penawaran, akan berkurang akibat permintaan dari masyarakat menurun.

Keputusan Pemerintah untuk menaikkan harga bahan bakar minyak (BBM) secara langsung (tahap pertama) menambah beban biaya operasi kendaraan angkutan umum. Pada tahap kedua, biaya ini akan meningkat lagi dengan terjadinya peningkatan harga komponen dan suku cadang kendaraan bermotor. Di sisi lain, tarif angkutan umum masih ditetapkan oleh Pemerintah dan diupayakan untuk tidak naik dalam rangka memberikan pelayanan 
transportasi yang murah kepada masyarakat luas. Dampak kenaikan minyak dunia yang mengakibatkan pemerintah mengurangi subsidi untuk minyak dalam negeri sehingga harus dinaikkannya harga bahan bakar minyak (BBM). Akibatnya secara langsung berdampak terhadap dinaikkan tarif angkutan umum.

Menurut Kotler (2011:83) definisi pelayanan adalah setiap tindakan atau kegiatan yang dapat ditawarkan oleh suatu pihak kepada pihak lain, yang pada dasarnya tidak berwujud dan tidak mengakibatkan kepemilikan apapun. Pelayanan angkutan kelas ekonomi, yang sering kali dianggap sebagai kewajiban pelayanan umum, telah dicoba untuk diatur sehingga masyarakat berpenghasilan rendah dapat memiliki berbagai aksesibilitas dalam aktivitas kesehariannya.

Jadi transportasi adalah sarana yang sangat penting dalam memperlancar roda perekonomian, mempererat persatuan dan kesatuan bangsa serta dapat mempengaruhi semua aspek kehidupan bangsa dan negara. Tersedianya transportasi yang memadai dalam satu daerah atau negara dapat memperlancar aktivitas masyarakatnya serta dapat meningkatkan pertumbuhan ekonomi bangsa atau negara tersebut. Transportasi juga merupakan suatu proses perpindahan suatu barang atau orang (penumpang) dari suatu tempat ke tempat lain. Dengan berpindahnya manusia dari satu tempat ke tempat lain melalui pengangkutan maka produktifitasnya akan bertambah tinggi. Karena memperoleh nilai tambah, maka pemilik barang maupun manusia (penumpang) bersedia memberikan balas jasa. Balas jasa sering disebut ongkos (tarif).
B. Rumusan Masalah

Berdasarkan latar belakang di atas maka rumusan masalahnya adalah "Apakah Pengaruh Kenaikan Harga Bahan Bakar Minyak (BBM) Terhadap Pelayanan Transportasi Roda Dua di Pasar Tiga Putri KM 14 Banyuasin ?"

\section{Metode Penelitian}

Menurut Sugiyono (2013:2) metode penelitian merupakan cara ilmiah untuk mendapatkan data dengan tujuan dan kegunaan tertentu. Metode yang digunakan dalam hal ini adalah metode assosiatif yang bertujuan untuk mengetahui pengaruh antara dua variabel atau lebih.

D. Populasi dan Sampel

1) Populasi

Populasi menurut Sugiyono (2013:115) adalah wilayah generalisasi yang terdiri atas objek/subyek yang mempunyai kualitas dan karakteristik tertentu yang ditetapkan oleh peneliti untuk dipelajari dan kemudian ditarik kesimpulannya. Populasi dalam penelitian ini, sebanyak 100 pengojek yang biasa mangkal di pinggiran pasar Tiga Putri KM 14 Banyuasin.

\section{2) Sample}

Sample menurut Sugiyono (2013:116) adalah bagian dari jumlah dan karakteristik yang dimiliki oleh populasi tersebut. Bila populasi besar dan peneliti tidak mungkin mempelajari semuanya, maka peneliti dapat menggunakan sample yang diambil dari populasi. Pada penelitian ini, penulis menggunakan teknik Accidental sampling atau pengambilan sample dimana seseorang diambil sebagai sample karena kebetulan orang tersebut ada atau dijumpai, untuk menentukan besarannya jumlah responden atau sample didasarkan pada pendapat Umar (2013:78) 
menggunakan rumus Slovin sebagai berikut :

$$
n=\frac{N}{1+n e^{2}}
$$

Keterangan :

$\mathrm{n}$ = Banyaknya sample

$\mathrm{N}$ = Banyaknya Populasi

e = Tingkat Kesalahan 10\%

Maka besarnya sample adalah

$\mathbf{n}=\frac{100}{1+(100)(0.1)^{2}}=\frac{100}{1+(100)(0.01)}$

$\mathrm{n}=\frac{100}{1+1}=\frac{100}{2}=50$ pengojek

Jadi, sample yang akan di teliti adalah 50 Pengojek.

\section{E. Teknik Pengumpulan Data}

Sugiyono (2015:193) menyatakan bahwa Data Primer adalah sumber data yang langsung memberikan data kepada pengumpul data. Adapun cara yang digunakan sebagai berikut :

1. Wawancara atau interview adalah sebuah proses memperoleh keterangan untuk tujuan penelitian dengan cara tanya jawab sambil bertatap muka antara pewawancara responden atau orang yang diwawancarai,dengan atau tanpa menggunakan pedoman (guide) wawancara.

2. Observasi atau pengamatan adalah kemampuan seseorang untuk menggunakan pengamatannya melalui hasil kerja pancaindra mata serta dibantu dengan pancaindra lainnya.

3. Angket atau Kuesioner adalah suatu teknik atau cara pengumpulan data secara tidak langsung (peneliti tidak langsung bertanya-tanya dengan responden).
F. Teknik Analisis Data

1) Analisis Regresi Linier Sederhana

Menurut Riduwan dan Akdon (2011:133) regresi sederhana digunakan untuk meramalkan atau memprediksi variabel terikat $(Y)$ apabila variabel bebas $(X)$ diketahui. Persamaan regresi dirumuskan:

$$
\hat{\mathrm{Y}}=\mathrm{a}+\mathrm{bX}
$$

\section{2) Analisis Koefisien Korelasi Sederhana ( $r$ )}

Menurut Sugiyono (2013:228) analisis koefisien korelasi ini dimaksudkan untuk mengetahui pengaruh antara dua variabel yang diteliti, yaitu variabel kenaikan harga bahan bakar $(X)$ terhadap variabel $(Y)$ pendapatan jasa angkut roda dua. teknik ini digunakan untuk mengetahui derajat hubungan antara variable bebas (independent) dengan variabel terikat (dependent).

$$
r_{\mathrm{xy}}=\frac{n(\Sigma X Y)-(\Sigma X)(\Sigma Y)}{\sqrt{\left(n \sum X^{2}-(\Sigma X)^{2}\right]\left(n \sum Y^{2}-\left(\sum Y\right)^{2}\right\}}}
$$

Keterangan :

$r_{x y}:$ Koefisien Korelasi Validitas

$x \quad$ : Skor Butir, $y$ : Skor Total

$x^{2} \quad$ : Kuadrat Skor Butir

$y^{2} \quad$ : Kuadrat Skor Butir

$n \quad$ : Jumlah Responden

Tabel 1

Interpretasi Koefisien Korelasi Nilai r

\begin{tabular}{|c|c|}
\hline $\begin{array}{c}\text { Interval } \\
\text { Koefisien }\end{array}$ & $\begin{array}{c}\text { Tingkat } \\
\text { Hubungan }\end{array}$ \\
\hline $0,80-1,000$ & Sangat Kuat \\
$0,60-0,799$ & Kuat \\
$0,40-0,599$ & Cukup Kuat \\
$0,20-0,399$ & Rendah \\
$0,00-0,199$ & Sangat Rendah \\
\hline \multicolumn{2}{|c|}{ Sumber : Sugiyono (2013:228) }
\end{tabular}




\section{3) Uji t}

Uji t dilakukan untuk mengetahui ada tidaknya pengaruh yang signifikan anatar kedua variable. Menurut Priyatno (2015:58), uji t digunakan untuk mengetahui apakah variabel Independent $(\mathrm{X})$ berpengaruh secara signifikan terhadap variabel Dependent (Y). Signifikan artinya meyakinkan atau pengaruh yang terjadi dapat berlaku untuk populasi.

Hipotesis:

$\mathrm{Ha}$ : Diduga ada pengaruh antara kenaikan harga bahan bakar minyak (BBM) terhadap pelayanan transportasi roda dua.

Ho :Diduga tidak ada pengaruh kenaikan harga bahan bakar minyak (BBM) terhadap pelayanan transportasi roda dua.

Pengambilan Keputusan :

- Jika nilai P-Value < 0,05 Maka Ha diterima, Jika nilai P-Value $>0,05$ Maka Ha ditolak

- Jika nilai P-Value > 0,05 Maka $\mathrm{H}_{0}$ diterima, Jika nilai P-Value $<0,05$ Maka $\mathrm{H}_{0}$ ditolak

G. Hasil Penelitian

1) Hasil Uji Coba Instrumen
Penelitian ini bertujuan untuk mengetahui pengaruh kenaikan harga bahan bakar minyak "BBM" terhadap pelayanan transportasi roda dua di pasar Tiga Putri KM 14 Banyuasin dilakukan dengan cara menggunakan analisis korelasi dan regresi linier sederhana. Sebelum analisis korelasi dan regresi linier sederhana digunakan, terlebih dahulu peneliti melakukan uji coba instrument penelitian (kuisoner) untuk menyatakan validitas dan reliabilities. Uji validitas dan reliabilitas untuk mengetahui istrumen penelitian yang alat ukur valid atau dapat dipercaya. Peneliti melakukan uji coba kepada 50 pengojek dipasar Tiga Putri KM 14 Banyuasin dengan menyebarkan kuisoner kepada 50 pengojek. Kuisoner tersebut berisikan 20 butir pertanyaan yang terbagi menjadi 2 (dua) variabel dengan 10 butir pertanyaan setiap variabel.

\section{a) Hasil Uji Normalitas}

Analisis normalitas suatu data ini akan menguji data variabel bebas (X) dan data variabel terikat (Y) pada persamaan regresi yang dihasilkan. Persamaan regresi dikatakan baik jika mempunyai data variabel bebas dan variabel terikat berdistribusi mendekati normal atau normal sama sekali. Uji normalitas menggunakan ini uji normalitas Kolmogorov-Smirnov.

Tabel 2

Hasil Uji Normalitas

One-Sample Kolmogorov-Smirnov Test

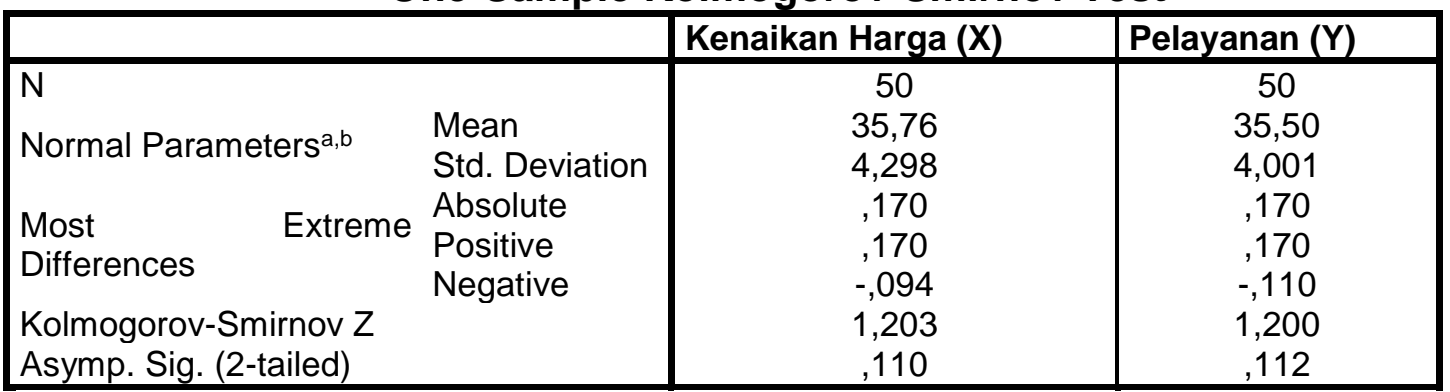

a. Test distribution is Normal.

b. Calculated from data.

Sumber : Data diolah 2017 
Berdasarkan output di atas dapat diketahui nilai signifikansi Kenaikan harga $(X)=0,110>0,05$ berarti data kenaikan harga $(X)$ adalah berdistribusi normal, sedangkan untuk nilai signifikansi Pelayanan $(\mathrm{Y})=0,112>$ 0,05 berarti data Pelayanan (Y) adalah berdistribusi normal.

b) Hasil Uji Normalitas

\section{Hasil Uji Validitas Kenaikan Harga (X)}

Uji validitas digunakan untuk menggukur sah atau tidaknya suatu butir pertanyaan. Skala butir pertanyaan disebut valid, jika melakukan apa yang seharusnya diukur dengan cara melakukan uji signifikansi koefisien korelasi pada taraf singinifikan 0,05 yang artinya suatu item dianggap valid jika berkorelasi signifikan terhadap skor total item. Uji validitas Kenaikan Harga (X) dengan menggunakan SPSS 20 for windows yaitu dengan hasil sebagai berikut:

\section{Tabel 3}

Hasil Uji Validitas

Variabel Kenaikan Harga ( X )

\begin{tabular}{|c|c|c|c|}
\hline Item & $\begin{array}{c}\text { P-Value } \\
\mathbf{\alpha ~ 0 , 0 5}\end{array}$ & Signifikan & Keterangan \\
\hline Pertanyaan 1 & 0,05 & 0,000 & Valid \\
\hline Pertanyaan 2 & 0,05 & 0,000 & Valid \\
\hline Pertanyaan 3 & 0,05 & 0,000 & Valid \\
\hline Pertanyaan 4 & 0,05 & 0,000 & Valid \\
\hline Pertanyaan 5 & 0,05 & 0,000 & Valid \\
\hline Pertanyaan 6 & 0,05 & 0,000 & Valid \\
\hline Pertanyaan 7 & 0,05 & 0,002 & Valid \\
\hline Pertanyaan 8 & 0,05 & 0,002 & Valid \\
\hline Pertanyaan 9 & 0,05 & 0,000 & Valid \\
\hline Pertanyaan 10 & 0,05 & 0,000 & Valid \\
\hline
\end{tabular}

Sumber : Data diolah 2017

Dari hasil pengelolahan data menggunakan program SPSS 22 for windows menunjukan bahwa hasil uji validitas dari 10 item pertanyaan variabel kenaikan harga $(X)$ pada taraf nyata $(\alpha)=5 \%$ keseluruhan valid. Dengan demikian keseluruhan item pertanyaan yang ada pada istrumen tersebut dapat dijadikan sebagai alat ukur yang valid dalam analisis selanjutnya.
2. Hasil Uji Validitas Pelayanan (Y)

Uji validitas digunakan untuk menggukur sah atau tidaknya suatu butir pertanyaan. Skala butir pertanyaan disebut valid, jika melakukan apa yang seharusnya diukur dengan cara melakukan uji signifikansi koefisien korelasi pada taraf singinifikan 0,05 yang artinya suatu item dianggap valid jika berkorelasi singifika terhadap skor total item. Uji validitas Pelayanan (Y) dengan menggunakan SPSS 20 for windows yaitu dengan hasil sebagai berikut: 
Tabel 4

Hasil Uji Validitas

Variabel Pelayanan ( Y )

\begin{tabular}{|c|c|c|c|}
\hline Item & $\begin{array}{c}\text { P-Value } \\
\text { a } 0,05\end{array}$ & Signifikan & Keterangan \\
\hline Pertanyaan 1 & 0,05 & 0,005 & Valid \\
\hline Pertanyaan 2 & 0,05 & 0,000 & Valid \\
\hline Pertanyaan 3 & 0,05 & 0,000 & Valid \\
\hline Pertanyaan 4 & 0,05 & 0,000 & Valid \\
\hline Pertanyaan 5 & 0,05 & 0,000 & Valid \\
\hline Pertanyaan 6 & 0,05 & 0,000 & Valid \\
\hline Pertanyaan 7 & 0,05 & 0,000 & Valid \\
\hline Pertanyaan 8 & 0,05 & 0,000 & Valid \\
\hline Pertanyaan 9 & 0,05 & 0,000 & Valid \\
\hline Pertanyaan 10 & 0,05 & 0,000 & Valid \\
\hline
\end{tabular}

Dari hasil pengelolahan data menggunakan program SPSS 22 for windows menunjukan bahwa hasil uji validitas dari 10 item pertanyaan variabel Pelayanan ( $\mathrm{Y}$ ) pada taraf nyata $(\alpha)=5 \%$ keseluruhan valid. Dengan demikian keseluruhan item pertanyaan yang ada pada istrumen tersebut dapat dijadikan sebagai alat ukur yang valid dalam analisis selanjutnya.

\section{c) Hasil Uji Reliabilitas}

1. Relibialitas Kenaikan Harga (X)

Uji reliabilitas di gunakan untuk mengukur suatu kuisoner yang merupakan indikator dari variabel. Reabilitas diukur dengan uji stastitik cronbach's alpha ( $\alpha$ ). Suatu variable dikatakan reliabel jika memberikan nilai cronbach's alpha $>0,06$. Hasil uji reliabilitas variabel Kenaikan Harga (X) dengan menggunakan SPSS 22 for windows yaitu dengan hasil.

\section{Tabel 5. Uji Reliabilitas Variabel Kenaikan Harga ( X )}

\begin{tabular}{|c|c|c|}
\hline $\begin{array}{c}\text { Cronbach's } \\
\text { Alpha }\end{array}$ & N of Items & $\begin{array}{c}\text { Hasil } \\
\text { Reabilitas }\end{array}$ \\
\hline, 819 & 10 & Reliabe \\
\hline
\end{tabular}

Sumber: Data diolah 2017

Hasil uji reabilitas didapat nilai

Cronbach' Alpha sebesar 0,819 > 0,6.
Karena nilai diatas 0,6 maka dapat disimpulkan bahwa alat ukur dalam penelitian ini realiabel dan dapat dijadikan alat ukur dianalisis selanjutnya.

\section{Reliabilitas Pelayanan (Y)}

Uji reliabilitas digunakan untuk mengukur suatu kuisoner yang merupakan indikator dari variabel. Reabilitas diukur dengan uji stastitik cronbach's alpha ( $\alpha$ ). Suatu variable dikatakan reliabel jika memberikan nilai cronbach's alpha $>0,06$. Hasil uji reliabilitas variabel pelayanan (Y) dengan menggunakan SPSS 22 for windows yaitu dengan hasil :

Tabel 6. Uji Reliabilitas Variabel Pelayanan ( $Y$ )

\begin{tabular}{|c|c|c|}
\hline $\begin{array}{c}\text { Cronbach's } \\
\text { Alpha }\end{array}$ & N of Items & $\begin{array}{c}\text { Hasil } \\
\text { Reliabilitas }\end{array}$ \\
\hline, 830 & 10 & Reliabel \\
\hline
\end{tabular}

Sumber: Data diolah 2017

Hasil uji reabilitas di dapat nilai Cronbach' Alpha sebesar 0,830>0,6. Karena nilai diatas 0,6 maka dapat disimpulkan bahwa alat ukur dalam penelitian ini realiabel dan dapat dijadikan alat ukur dianalisis selanjutnya. 
d) Hasil Teknik Analisis Data

1) Hasil Regresi Linier Sederhana

Analisis regresi linear berganda menggunakan SPSS 20 for windows yaitu dengan hasil :

Tabel 7

Regresi Linier Sederhana

\begin{tabular}{|c|c|c|c|c|c|}
\hline \multirow[t]{2}{*}{ Variabel } & \multicolumn{2}{|c|}{$\begin{array}{l}\text { Unstandardized } \\
\text { Coefficients }\end{array}$} & \multirow{2}{*}{$\begin{array}{c}\begin{array}{c}\text { Standardized } \\
\text { Coefficients }\end{array} \\
\text { Beta }\end{array}$} & \multirow[b]{2}{*}{$\mathbf{T}$} & \multirow[b]{2}{*}{ Sig. } \\
\hline & B & Std. Error & & & \\
\hline Kenaikan Harga & $\begin{array}{l}16,615 \\
, 528\end{array}$ & $\begin{array}{l}3,985 \\
, 111\end{array}$ & ,567 & $\begin{array}{l}4,169 \\
4,772\end{array}$ & $\begin{array}{l}, 000 \\
, 000\end{array}$ \\
\hline
\end{tabular}

a. Dependent Variable: Pelayanan

Dari tabel di atas menunjukan hasil pendugaan koefisien regresi dan pengujian secara parsial dengan uji_t. berdasarkan tabel tersebut diperoleh nilai koefisien regresi untuk kenaikan harga sebesar 0,528 Dan koefisien konstanta sebesar 16,615. Berdasarkan nilai tersebut diperoleh persamaan regresi linier sederhana adalah:

$Y=a+b X$

$Y=16,615+0,528$
Berdasarkan output coefficients diketahui nilai koefisien regresi kenaikan harga sebesar 0,528 dengan signifikansi $0,000 \%$ atau $0 \%<5 \%$ berarti signifikan untuk memprediksi nilai pelayanan. Dimana jika nilai $X$ naik sebesar satu satuan maka prediksi nilai $Y$ naik sebesar 0,528 dan sebaliknya jika berkurang satu satuan nilai $X$ maka prediksi nilai $Y$ berkurang sebesar 0,528 .

\section{2) Hasil Koefisien Korelasi Sederhana (r)}

Tabel 8

Model Summary

\begin{tabular}{|c|c|c|c|}
\hline $\mathrm{R}$ & $\mathrm{R}$ Square & Adjusted R Square & Std. Error of the Estimate \\
\hline $567^{\mathrm{a}}$ &, 322 &, 308 & 3,329 \\
\hline Sumber : Data diolah 2017 & &
\end{tabular}

Untuk melihat seberapa besar kuat hubungannya dapat dilihat dari nilai pearson correlation yaitu $\mathrm{R}=$ 0,567 . Maka dapat disimpulkan bahwa kekuatan hubungan antara kenaikan harga dengan pelayanan adalah cukup kuat atau sebesar $56 \%$. Selanjutnya analisis koefisien determinasi $\left(r^{2}\right)$ diperoleh nilai $r^{2}=0,322$. Hal tersebut dapat diartikan bahwa pelayanan yang dipengaruhi oleh kontribusi variabel kenaikan harga adalah $32,2 \%$, sedangkan sisanya $67,8 \%(100 \%$ $32,2 \%$ ) di pengaruhi oleh variabel lain yang tidak ikut di teliti dalam penelitian ini.

\section{3) Hasil Uji Hipotesis ( Uji t )}

Setelah diperoleh regresi hasil perhitungan koefisien korelasi antara kenaikan harga dan pendapatan jasa, selanjutnya dilakukan uji hipotesis dengan menentukan tingkat signifikansi menggunakan alpha $5 \%$ (Signifikansi $5 \%$ atau 0,05 adalah ukuran standart yang sering digunakan dalam penelitian).

> Hasil uji hipotesis ditampilkan pada tabel 9 berikut ini : 
Tabel 9

Uji t

Coefficients $^{a}$

\begin{tabular}{|c|c|c|c|c|c|}
\hline \multirow[t]{2}{*}{ Variabel } & \multicolumn{2}{|c|}{$\begin{array}{c}\text { Unstandardized } \\
\text { Coefficients }\end{array}$} & \multirow{2}{*}{$\begin{array}{r}\begin{array}{c}\text { Standardized } \\
\text { Coefficients }\end{array} \\
\text { Beta }\end{array}$} & \multirow[b]{2}{*}{$\mathbf{T}$} & \multirow[b]{2}{*}{ Sig. } \\
\hline & B & Std. Error & & & \\
\hline Kenaikan Harga & $\begin{array}{c}16,615 \\
, 528\end{array}$ & $\begin{array}{c}3,985 \\
, 111\end{array}$ & ,567 & $\begin{array}{l}4,169 \\
4,772\end{array}$ & $\begin{array}{l}, 000 \\
, 000\end{array}$ \\
\hline
\end{tabular}

Sumber ; Data diolah 2017

Berdasarkan tabel diatas, diperoleh nilai $p$-value (sig) variabel kenaikan harga $(X)$ sebesar 0,000, karena nilai p-value $0,000<0,05$, maka kriteria pengujian hipotesis $\mathrm{H}_{0}$ ditolak, $\mathrm{Ha}$ diterima, dari analisis tersebut dapat disimpulkan bahwa kenaikan harga berpengaruh signifikan terhadap pelayanan transportasi roda dua di Pasar Tiga Putri KM 14 Banyuasin.

\section{H. Pembahasan}

Dari hasil pengelolahan data menggunakan program SPSS 20 for windows menunjukan bahwa hasil uji validitas dari 10 item pertanyaan semua variabel pada taraf nyata $(\alpha)=$ $5 \%$ keseluruhan valid. Dengan demikian keseluruhan item pertanyaan yang ada pada istrumen tersebut dapat dijadikan sebagai alat ukur yang valid dalam analisis selanjutnya.

Hasil uji reliabilitas dapat dilihat pada output reliabilitas stasistik kenaikan harga dengan Cronbach'Alpha sebesar 0,819> 0,6 sedangkan untuk pelayanan dengan Crobach'Alpha sebesar $0,830>0,6$, dari nilai ditersebut maka dapat disimpulkan bahwa alat ukur dalam penelitian ini realiable dan dapat dijadikan alat ukur dianalisis.

Berdasarkan nilai tersebut diperoleh persamaan regresi linier sederhana adalah: $Y=16,615+$ 0,528X, berdasarkan output coefficients diketahui nilai koefisien regresi kenaikan harga sebesar 0,528 dengan signifikansi $0,000 \%$ atau $0 \%$ $<5 \%$ berarti signifikan untuk memprediksi nilai pelayanan. Dimana jika nilai $X$ naik sebesar satu satuan maka prediksi nilai $Y$ naik sebesar 0,528 dan sebaliknya jika berkurang satu satuan nilai $X$ maka prediksi nilai $Y$ berkurang sebesar 0,528.

Berdasarkan perhitungan model summary diperoleh nilai $\mathrm{R}=0,567$ hal ini berarti korelasi variabel kenaikan harga dengan pelayanan adalah cukup kuat atau sebesar 56\%, besarnya kontribusi dapat dilihat dari nilai $r^{2}=$ 0,322 , yang berarti besarnya kontribusi variabel kenaikan harga terhadap pelayanan adalah sebesar $32,2 \%$, sedangkan sisanya 67,8 \% ( $100 \%$ $32,2 \%$ ) di pengaruhi oleh variabel lain yang tidak ikut di teliti dalam penelitian ini.

Berdasarkan hasil pengujian hipotesis diperoleh nilai $\mathrm{p}$-value (sig) $0,000<0,0$, hal ini berarti $\mathrm{H}_{0}$ ditolak dan $\mathrm{Ha}$ diterima, maka dapat disimpulkan bahwa variabel kenaikan harga berpengaruh terhadap variabel pelayanan. Jadi dari hasil penelitian sebelumnya dapat disimpulkan bahwa variabel kenaikan harga (X) berpengaruh terhadap variabel pelayanan $(\mathrm{Y})$.

\section{Kesimpulan dan Saran \\ 1) Kesimpulan}

Berdasarkan perhitungan regresi linear sederhana nilai koefisien regresi untuk kenaikan harga sebesar 0,528 dan koefisien konstanta sebesar 
16,615, berdasarkan nilai tersebut diperoleh persamaan regresi linier sederhana adalah : $Y=16,615+$ 0,528X, dan output coefficients diketahui nilai koefisien regresi kenaikan harga sebesar 0,528 dengan signifikansi $0,000 \%$ atau $0 \%<5 \%$ berarti signifikan untuk memprediksi nilai pelayanan. Dimana jika nilai $X$ naik sebesar satu satuan maka prediksi nilai $Y$ naik sebesar 0,528 dan sebaliknya jika berkurang satu satuan nilai $X$ maka prediksi nilai $Y$ berkurang sebesar 0,528.

Berdasarkan hasil pengujian dengan menggunakan program SPSS Versi 22 maka didapat nilai Uji-t diperoleh nilai $p$-value (sig) variabel kenaikan harga $(X)$ sebesar 0,000, karena nilai p-value $0,000<0,05$, maka kriteria pengujian hipotesis $\mathrm{H}_{0}$ ditolak, $\mathrm{Ha}$ diterima, dari analisis tersebut dapat disimpulkan bahwa kenaikan harga berpengaruh signifikan terhadap pelayanan roda dua di Pasar Tiga Putri KM 14 Banyuasin.

\section{2) Saran}

a) Hendaknya pihak-pihak yang terkait dengan persoalan angkutan jasa atau ojek, terutama pemerintah Kabupaten Banyuasin segera membantu menentukan tempat pemasaran jasa dan strategi yang tepat dalam memasarkan jasa angkut atau ojek di Banyuasin sehingga tidak terjadi persaingan harga pada jasa angkutan atau ojek.

b) Hendaknya para pengojek dapat membuat suatu organisasi yang digunakan sebagai tempat musyawarah para pengojek. Sehingga tidak terjadi persaingan usaha antar pengojek yang mana organisasi tersebut digunakan sebagai wadah kerja sama antar pengojek. c) Hendaknya para pengojek menemukan strategi pengembanganpengembangan baru, peningkatan SDM yang berkualitas sehingga selalu berupaya untuk mempertahankan dan meningkatkan kelangsungan hidup pengojek pada saat terdapat kebijakan kenaikan harga Bahan Bakar Minyak (BBM) dan ketatnya persaingan ekonomi global dewasa ini.

d) Para pengojek sebaiknya melakukan pengembangan teknologi, dengan mengikuti perkembangan teknologi yang ada, mereka akan dapat mampu berkompetisi di pasar modern melalui penjualan jasa yang khas, higienis, dan terjangkau.

\section{DAFTAR PUSTAKA}

Husein, Umar, 2013, Metode Penelitian Untuk Skripsi dan Tesis Bisnis, Nusa Media, Bandung.

Kottler, Philip, 2011. Manajemen Pemasaran edisi Kesebelas. Indeks. Jakarta.

Priyatno, Duwi, 2015. SPSS 22 Pengolahan Data Terpraktis. Edisi Pertama. Alfabeta Bandung

Riduwan. 2011. Belajar Mudah Penelitian.Alfabeta, Bandung

Sugiyono, 2013, Metode Penelitian Bisnis (MPB), Penerbit Alfabeta, Bandung.

Sugiyono. 2015. Metode Penelitian Kuantitati Kualitatif dan $R \& D$.Alfabeta. Bandung 